\title{
Scabbards and Belt Fittings
}

The buckles and various carrying rings constitute a small group of artefacts found at the El-Zuma cemetery [Fig. 15.1]. Items identified as belt elements were discovered only in three tumuli. In all three cases they were found alongside edged weapons.

\section{1}

\section{Scabbards and Belt Elements}

Two copper-based buckles $\mathrm{Z}_{4} / 2 \mathrm{O}$ [Cat. 1] and $\mathrm{Z}_{4} / 81$ [Cat. 2] were found in T.4. Buckle $\mathrm{Z}_{4} / 20$ was made of brass, as confirmed by XRF tests (see Chapter 19, this volume). This object is of relatively simple construction. It was made of D-shaped brass wire as a two-part model (frame and pin). The construction technique used for the second buckle $\left(\mathrm{Z}_{4} / 81\right)$ was much more complicated. Apart from the frame and pin, it consisted of an attachment plate wrapped around the bar. The front of this triangular plate was embossed (slightly convex), and had a rivet in each of its three corners to fix it to the belt. The attachment to the belt was reinforced with a rectangular backplate.

This construction was a typical solution for military belts, which must have additional reinforcements and fittings on top due to the possibility of being cut in combat, as well as the additional weight they have to bear when a weapon is suspended from them. These buckles could be parts of two belts used to attach a weapon, but we cannot state this with certainty because all objects from T.4 came from the tunnel.

A broken and contorted forged iron loop Z16/36, [Cat. 4] was found in T.16. Its longer side measures $2.6 \mathrm{~cm}$ on the inside, which means that this was the maximum width of the belt. The shorter side measures $1.4 \mathrm{~cm}$ in the middle (the widest point). Unfortunately, no evidence of a pin was found. However, due to its very poor condition, it cannot be ruled out that this object originally had such a pin.

Object $\mathrm{Z}_{10} / 45$ [Cat. 3], found in T.10, is a fragment of two thick, longitudinal iron strips terminating in a sleeve with an iron ring. The object was broken in half, so the other end does not survive. Originally, it would have consisted of three strips and a second iron ring at the opposite end. The middle strip is semi-circular in cross-section. The whole object was probably a scabbard locket with a carrying ring still extant at one end.

Buckle finds in Nubian assemblages are very rare. One example was found at the West Cemetery in Meroe in grave W114 (Dunham 1963, 227, Fig. 158), associated with ox bones and dated to $\mathrm{AD} 60-70$. Other specimens were recorded in the private cemeteries at Ballana and Qustul and dated to the $4^{\text {th }}-5^{\text {th }}$ century AD (Williams 1991, 127128, Pl. 73e). Both the buckle from Meroe and the examples from El-Zuma are identical to Roman buckles of the 4th to 5 th century AD (Soupault 2003; Forum Ancient Coins 2019; Roman Coins n.d.), which were used only by the Roman army. Mountings for horse and camel equipment found in Ballana and Qustul do not feature any buckles (Emery and Kirwan 1938, 251-262). Many big combat knives with scabbards (described as swords) were found in Ballana and Qustul, but no buckles are mentioned by Emery (Emery and Kirwan 1938, 219-221). However, the custom of wearing edged weapons by using two belts is known from Meroitic iconography. Examples include a relief depicting warriors on the lower podium of temple M250 in Meroe (Török, Hofmann, and Nagy 1997, Pl. 72) and the iconography of a Meroitic king (Shinnie 1967, Pl. 33; Zieliński 2011, Figs 52, 54). The characteristic use of rings for mounting sword scabbards can be seen in both cases, and could provide an analogy for artefact Z1o/45 from ElZuma.

Roman influences in the post-Meroitic period can be seen in different categories of burial equipment: for example, in the horse equipment from Ballana (Emery and Kirwan 1938, 251-253), but also in the buckles discovered in El-Zuma. The custom of hanging an edged weapon from two belts is very practical and, as detailed above, has been noted in Meroitic as well as Roman contexts. Since Nubia was a direct neighbour of Roman Egypt, it is quite possible that Roman-style objects were imported and used in the same way as they were by the Romans (in this instance, for carrying weapons).

Fragmentarily preserved long combat knives were found in T.16 and T.1o, and a regular knife in T.1o. In addition, fragments of a large dagger were found in T.4, as well as the sleeve (handguard) of a second smaller knife. A large number of indeterminate fragments also found in T.4 may be the remains of another combat knife judging by their dimensions.

The $\mathrm{Z}_{4} / 81$ belt loop had meticulously made fittings typical of belts, in particular ones designed to carry weapons. The Z10/45 fragment is very corroded and heavily damaged, but some characteristic traits of a scabbard mounting can still be distinguished. One of them is a small ring 


\section{SCABBARDS AND BELT FITTINGS}

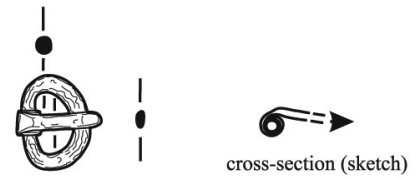

Cat. 1

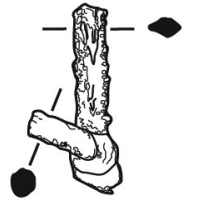

Cat. 3

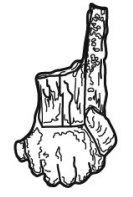

$Z 10 / 45$

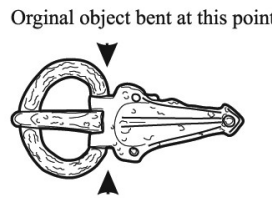

Cat. 2

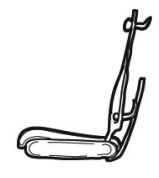

Z4/81

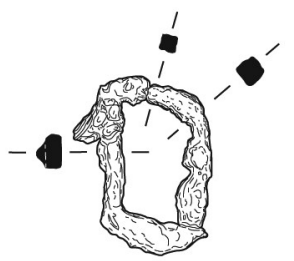

Cat. 4

Z16/36

0 $5 \mathrm{~cm}$

FIGURE 15.1 Scabbards and belt fittings

Z4/20, Z4/81, Z16/36 DRAWN AND DIGITISED BY Ł. ZIELIŃSKI; Z1O/45 DRAWN BY A.

BŁASZCZYK, DIGITISED BY Ł. ZIELIŃSKI

for fixing the scabbard to a belt. Another is the reinforced plate of the scabbard neck. In examples from the royal cemeteries of Ballana and Qustul dated to the 5th-6th century AD (Emery and Kirwan 1938, 219-221), the whole scabbard was decorated with silver sheets, but Z1o/45 from El-Zuma is a more utilitarian version made of iron.

In the case of T.4, all metal finds were found mixed up in the tunnel, having been disturbed by robber activity. This was not the case with T.10, where all of the finds came from the burial chamber. On the other hand, in the case of T.16, loop Z16/36 was found in the immediate vicinity of the skeleton, while the weapons (long combat knife included) were found mainly in the shaft, but still close to the disturbed blocking wall of the burial chamber.

\section{$2 \quad$ Catalogue}

\section{Cat. 1}

Brass buckle

Inv. no.: $\mathrm{Z}_{4} / 20$

Context data: Tumulus 4, Layer 5

Dimensions: Frame: $2.2 \times 1.6 \mathrm{~cm}, \mathrm{D}=0.4 \mathrm{~cm}$; pin: $\mathrm{L}=2 \mathrm{~cm}$,

$$
\mathrm{W}=0.4 \mathrm{~cm}, \mathrm{Th}=0.2 \mathrm{~cm}
$$

Material and technique: Brass

Description: Brass buckle (in good shape).
Cat. 2

Buckle

Inv. no.: $\mathbf{Z}_{4} / 81$

Context data: Tumulus $4, \mathrm{~W}$ tunnel

Dimensions: Frame: $2.8 \times 2.1 \mathrm{~cm}, \mathrm{D}=0.4 \mathrm{~cm}$; pin: $\mathrm{L}=2.4 \mathrm{~cm}$, $\max \mathrm{W}=0.55 \mathrm{~cm}$; plate: $\mathrm{L}=3.7 \mathrm{~cm}, \max \mathrm{W}=1.9 \mathrm{~cm}$, $\mathrm{Th}=0.3 \mathrm{~cm}$

Material and technique: Copper alloy

Description: Buckle with triangular plate featuring three rivets.

Cat. 3

Scabbard fitting fragment

Inv. no.: $\mathrm{Z1o} / 45$

Context data: Tumulus 10, burial chamber

Dimensions: D $=0.6 \mathrm{~cm}$, side rod cross-section $0.6 \mathrm{~cm} \times$ $0.8 \mathrm{~cm}$, middle rod diameter $1.1 \mathrm{~cm}$ (rounded)

Material and technique: Iron

Description: One heavily corroded and broken iron fragment of scabbard fitting.

Cat. 4

Rectangular loop, reassembled from two fragments

Inv. no.: Z16/36

Context data: Tumulus 16, chamber 1, part S, near skeleton Dimensions: $3.7 \mathrm{~cm} \times 2.4 \mathrm{~cm}$ (inside $2.6 \mathrm{~cm} \times 1.4 \mathrm{~cm}$ ), 
cross-section varies (square $0.4 \mathrm{~cm}$ cross-section on shorter side, rectangular $0.4 \mathrm{~cm} \times 0.5 \mathrm{~cm}$ on longer side)

Material and technique: Forged iron (from one piece)

Description: Loop which, under the weight of surrounding soil, deformed into a rhombus (but originally must have been rectangular). The object is heavily corroded on the surface and has a cracked core; pieced together from two fragments.

References: Zieliński 2014, 387 